\title{
Waterfront Public Space Planning on Krueng Aceh River in Banda Aceh-Indonesia
}

\author{
Rizqa Uswah, Lin Wang \\ Department of Architecture, Shanghai Jiao Tong University, Shanghai, China \\ Email: rizqauswah@gmail.com, wanglinalice@sjtu.edu.cn
}

How to cite this paper: Uswah, R., \& Wang, L. (2021). Waterfront Public Space Planning on Krueng Aceh River in Banda Aceh-Indonesia. Current Urban Studies, 9, 218-226.

https://doi.org/10.4236/cus.2021.92014

Received: April 9, 2021

Accepted: May 29, 2021

Published: June 1, 2021

Copyright $\odot 2021$ by author(s) and Scientific Research Publishing Inc. This work is licensed under the Creative Commons Attribution International License (CC BY 4.0).

http://creativecommons.org/licenses/by/4.0/

\section{(c) (i) Open Access}

\begin{abstract}
Urban waterfront development had been a global trend in many cities around the world, not only in big cities but also in medium-sized cities, and even small towns. They have improved their waterfront area with good utilization in order to create attractive public spaces. Located on the most western tip of Sumatera Island in Indonesia, the riverbank area along Krueng Aceh River in Banda Aceh is undergoing to waterfront oriented and has enormous potential to be developed as waterfront public space. But in its implementation, there is still less waterfront utilization so which affects the lack of urban public space quality improvement along the riverbank. This paper presents the waterfront planning on Krueng Aceh River in Banda Aceh, Indonesia, and provides a strategic plan as a new waterfront concept in terms of urban public space quality improvement that can be applied immediately.
\end{abstract}

\section{Keywords}

Urban Waterfront Development, Waterfront Planning, Urban Public Space Quality Improvement

\section{Introduction}

Waterfront has an important role for the people live and it will be continuous all the time. Urban waterfront development had been a global trend in many cities around the world, not only in big cities but also in medium-sized cities, and even small towns, they have begun to develop their waterfronts into open public spaces in order to improve urban space quality. As stated by Erkök (2009), many cities around the world are creating ambitious waterfront projects, trying to solve their problems related to environmental preservation and combining them with improved public spaces.

London's waterfront has transformed from exploited river that people used 
for trade through water and not livable into first class waterfront where people enjoy life and created a great dockland which is the largest port in the world (Global Waterfront Talk, 2016). In Australia, Sydney's Darling Harbor has been transformed from the once derelict docklands into a city display and tourism center, and the urban waterfront in Melbourne has been redeveloping to represent the city's globally oriented, economically focused, consumption-based urban strategy (Davidson, 2009). By faced urban problems from declining of industrial area, emerging of slum area and environmental problems, Zanzibar's Stone Town waterfront in Tanzania was given spatial restructuring included the relocation of port industry, preservation of ferry and passenger facilities, opening public spaces and retail facilities, reintegration and restoration of the Culture Center (Pramesti, 2017).

Waterfront development provides various opportunities such as sustainable development, ecological environment, and ecosystem protection. Urban waterfronts can help restore or enhance the vitality of urban developments, improve local environments, seize development opportunities, and reshape regional characteristics and image (Wu et al., 2019). By good utilization of waterfront area in urban space, the city and its people can achieve some advantages such as aesthetic image and recreational opportunities, better community life, improved public space, increased land values and supported economic development. As stated by Breen et al. (1994), the need to improve environmental quality, the availability of abandoned waterfront sites, the pressure upon urban space and infrastructure brought about by urbanization have led the waterfront redevelopment as a fitting solution (Pramesti, 2017).

For example, Shanghai is one of big cities in the world and one of famous cities in China that has an excellent waterfront development along Huangpu River. The river has changed dramatically and grew into a waterfront that is parallel to some famous global waterfronts around the world. Through urban regeneration, from the largest China's riverside industrial development, Huangpu Riverside has transferred from industrial basis of shipping and manufacturing to a place with finance, trade, and tourism at the core of its development. The river affords its high quality improvement waterfront urban spaces under the theme of innovation expo, culture experience and ecological entertainment. Transformation of waterfront space in Shanghai points out that the urban waterfronts with geographical advantages and historical values have the potential to provide a powerful impetus to the economic and social development of the city (Chen, 2009).

Located on the most western tip of Sumatera Island in Indonesia, the riverbank area along Krueng Aceh River in Banda Aceh is undergoing to waterfront oriented and has enormous potential to be developed as waterfront public space. But in its implementation, there is still less waterfront utilization such as inactive and abandoned area, rarely visited by local community, no greenway, and less 
comfortable pedestrians, even the worst is many slums caused by misuse of waterfront function such as street vendor, parking area, and landfill in some other areas where has not been built yet.

Therefore, this paper focuses on a study of waterfront public space planning of Krueng Aceh River in Banda Aceh-Indonesia, involving urban space quality improvement in riverside area. With the ultimate aim in mind as drawing a new waterfront concept for Krueng Aceh River, it investigates comprehensively the appropriate potentials of Krueng Aceh River as waterfront public space to generate the strategic plan that can be applied immediately. The new waterfront planning strategy is expected to be able to give effort reflecting city's identity of Banda Aceh, although it is not a popular city but its waterfront have own characteristics as well as big cities.

\section{Waterfront Planning on Krueng Aceh River}

\subsection{The Beginning of Waterfront Planning on Krueng Aceh River}

Banda Aceh is located on the most western tip of Sumatra Island in Indonesia. Geographically, the position of Banda Aceh has direct boundaries with Strait of Malacca on the North and Indian Ocean on the West. The city is the capital of Aceh Province with a total area approximately $61.36 \mathrm{~km}^{2}$ and consist 9 districts and 17 sub-districts. The population of Banda Aceh by the year of 2017 is 259,913 people with the highest density in range of 4236 people/sq.km especially in the city center where is a regional trade and government center both of city and province level (Statistics of Banda Aceh City, 2018).

Krueng Aceh River is one of the rivers in Aceh Province which has approximately $145 \mathrm{~km}$ length and several tributaries flow into the river body. The beginning of waterfront planning along Kreung Aceh River in Banda Aceh was carried out in 1990s, when the river is still used as landfill. At that time, the Government of Banda Aceh under Public Works and Spatial Planning Agency began to work on developing the riverbank area. Hence, there has been made some planning for waterfront development continuously until now. With the ability of the budget, the riverbank area of Krueng Aceh River is slowly already organized, start not backing up, and aware of the river environment.

In 26th December 2004, Indian Ocean Earthquake and Tsunami disaster occurred and destroyed most part of Banda Aceh. The coastal area at the river mouth was one of the worst affected areas that many buildings, social-economic facilities, urban utility, and transportation route completely destroyed to the ground, besides around 70.000 fatalities. Krueng Aceh River was also affected by the disaster that swept water up some $40 \mathrm{~km}$ of the river. After disaster, government endeavour to rebuild some urban facilities and utilities in order to rehabilitation and redevelopment especially in the worst affected area. Literally, the development of both riverbanks along Krueng Aceh River is included the first priority in the implementation of strategic area as waterfront development. 
Then, the first waterfront planning on Krueng Aceh River has ever been drafted in 2008 as Development Guidance of Krueng Aceh River Segment II where is located in the city center with intervention area around $208,000 \mathrm{~m}^{2}$. It was directed by Banda Aceh's Government and supported by GTZ-SLGSR as a bilateral cooperation between Indonesia and Germany. This guidance is considered as Master Plan and basis for building and environmental planning. Nevertheless a dynamic concept, it was changed regularly to adjust changing condition and needs, also ensuring urban development in accordance with the strategies and regulation of Banda Aceh (Government of Banda Aceh City, 2008).

\subsection{The Potential of Krueng Aceh River as Waterfront Public Space}

The riverbank area along Krueng Aceh River in Banda Aceh has enormous potential to be developed as waterfront public space. The potentials are highlighted below:

1) Heritage area of Aceh Sultanate and Islamic civilization center

The river has an important history of Aceh Sultanate in ancient times and a waterway of the beginning of religion entry in Indonesia. The sultanate of Aceh officially the Kingdom of Aceh was a Sultanate centered in Indonesian province of Aceh in 13th-19th centuries. After replacement of the Aceh Sultanate Palace from Pande Village to the city center of Koeta Radja (now Banda Aceh) by Sultan Alaidin Mahmudsyah (1267-1309), at that time, the situation on the Aceh River is very crowded by the large ships from overseas that carried trading goods until to the heart of the city. Until now, the river has played an important role in supporting community activities of Banda Aceh municipality such as fishing, trade route, and water utility system.

2) The role of protected and strategic area

Krueng Aceh River has two important roles at once, based on the policy and development strategy of urban space pattern of Banda Aceh, Krueng Aceh River is included into two categories at once (Figure 1). 1) Protected area aims to provide protection against environmental sustainability that includes natural resources and artificial resources, to maintain water supply (hydrological function), and is expected to preserve the macro climate environment (Ministry of Public Works and People's Housing of Indonesia, 2011). The river is strived for maintaining environmental protection in term of urban sustainable development in long-term period. 2) Strategic area aims to develop and to improve urban economic growth that productive, efficient, and able to compete in regional and national level; cultural and historical preservation; and encouragement of new urban development in the future (Government of Banda Aceh City, 2009a). The river is directed for waterfront revitalization as public space in order to encourage new urban development to improve urban space quality along the riverbank.

3) Waterfront City (WFC) Development 

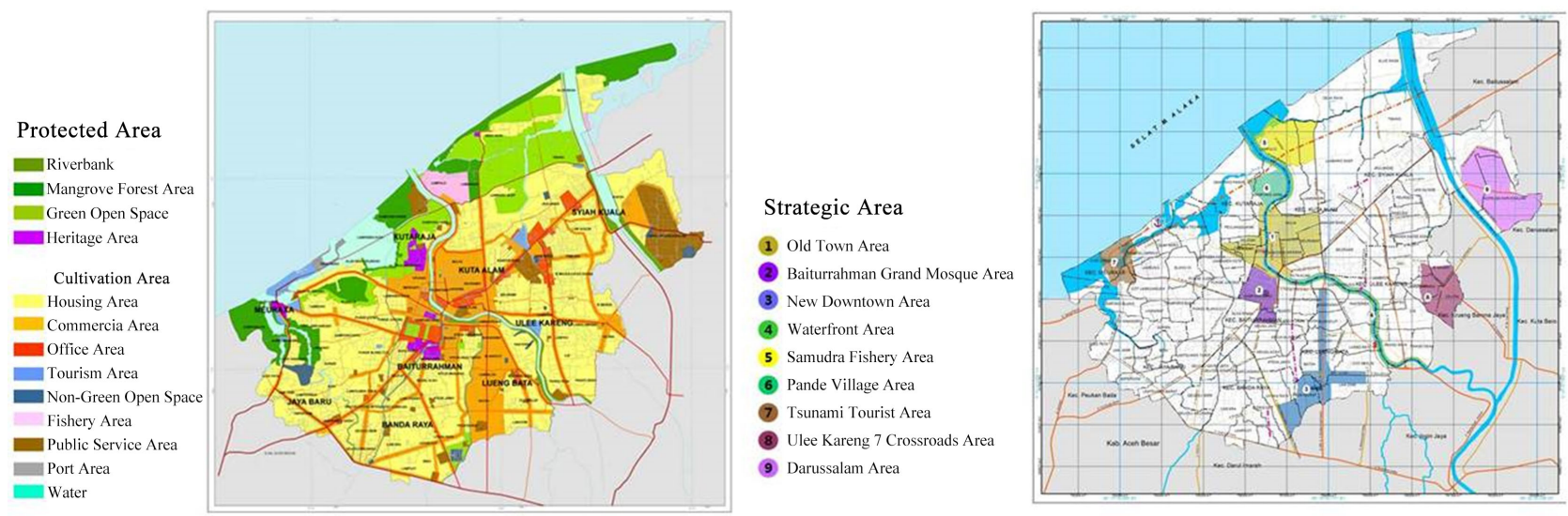

Figure 1. Protected Area (left), Strategic Area (right). Source: Urban spatial planning of Banda Aceh 2009-2029.

After the big earthquake and tsunami disaster in 2004, the riverbank along Krueng Aceh River is included into the first implementation priority as waterfront development. It is in accordance with the directions contained in Regional Regulation of Banda Aceh No.4 year of 2009 about Urban Spatial Planning of Banda Aceh City 2009-2029 paragraph 3 regarding River Transportation System article 32 which reads: "The Krueng Aceh riverbank is built to support water transportation system, in line with Krueng Aceh River utilization as a water transportation route in the future to support the development of Waterfront City (WFC) area" (Government of Banda Aceh City, 2009b).

4) Islamic City

The waterfront development in Banda Aceh is more preferred in the city center area where is located on Old Town area and closed to Baiturrahman Grand Mosque which is an iconic building and the landmark of Aceh Province. The existence of Baiturrahman Grand Mosque is a city's identity of Islamic City and its function as cultural center with great historical value and has upgraded into religious tourism object.

5) Central Business area

Trade and commercial activities in the city center have grown since the early development of the city during Sultanate era in 13th century so there has high economic value and has economic growth potential. The area also was planned to support urban development of Banda Aceh Central Business (as known as Central Business District) in the future.

\section{Strategic Plan for Waterfront Public Space on Krueng Aceh River}

The strategic plan aims to generate new opportunity as a development guided in order to realize urban public space quality improvement on riverside area related to ecology, lifestyle and aesthetic image to maintain river environment, to be better community life, and to encourage recreational opportunities. So that, based on the identified potentials previously, the strategic plan for waterfront's 
public space of Krueng Aceh River can be generated to be applied as follow:

1) Planning Target

As a historical area of Aceh Sultanate and Islamic civilization center in ancient time, and still played a role in supporting community activities of the city, Krueng Aceh River can be considered to become Aceh Islamic Riverside that can be transformed into an attractive public space as the center of Acehnese Culture, Islamic City, Local Economic Development, and Water Transportation System.

2) Function Layout

According to physical zone division of urban space utilization, strategic area of Banda Aceh, and current situation of Krueng Aceh River, the main area of Krueng Aceh River and its function layout can be identified as shown on Table 1 and Figure 2.

3) Development Concept

In order to improve public space quality, the strategic plan for waterfront space on Krueng Aceh River can be guided by the development concept of "Islamic-based, Cultural-enriched, and River-oriented". It aims to endeavor strengthening the city's identity of Banda Aceh as Islamic City, to highlight the local wisdom of Acehnese Culture, and to realize waterfront public space not only as attractive view of the city but also for public interest to be actively used by citizen. Therefore, the strategic plan for waterfront's public space on Krueng Aceh River can be applied as shown on Table 2.

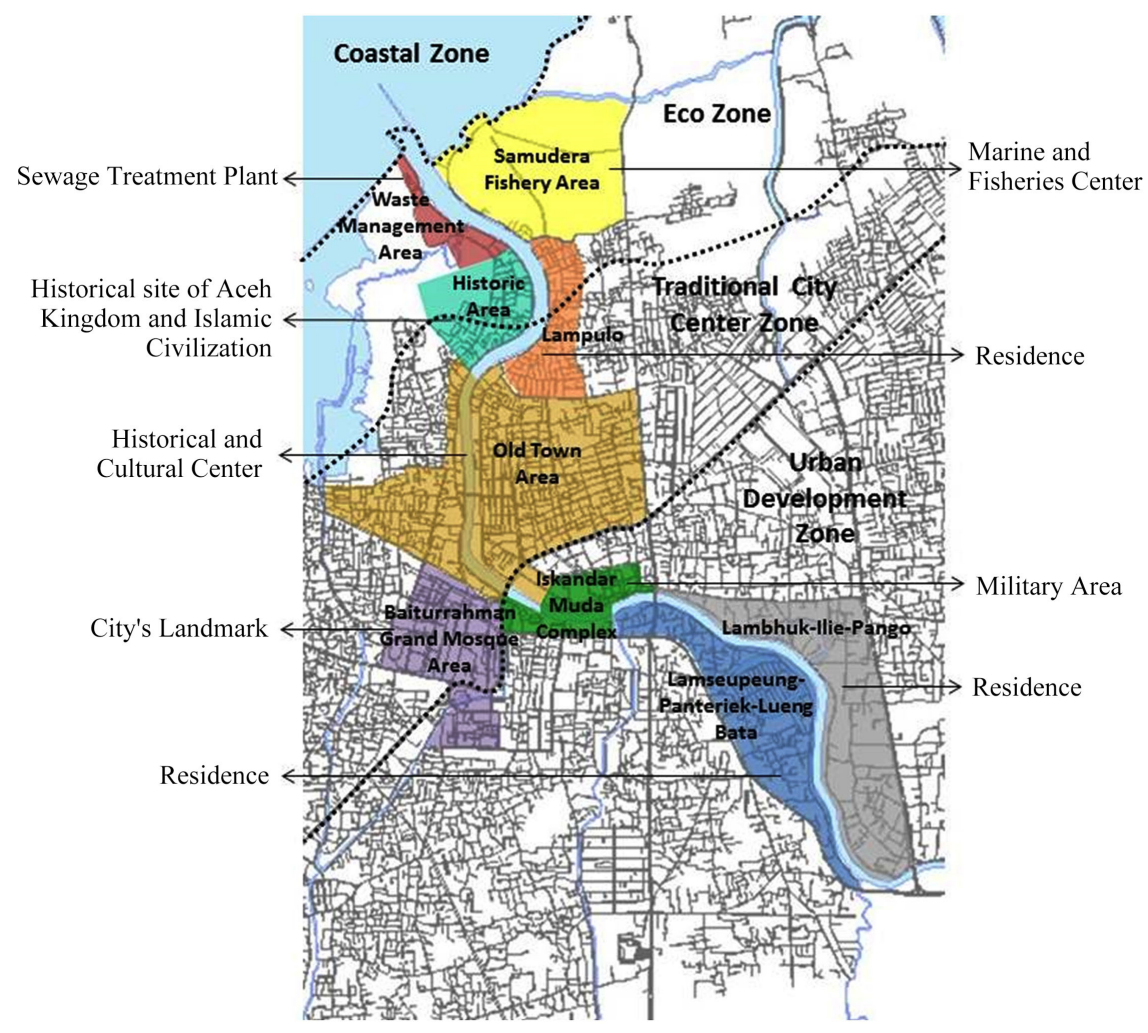

Figure 2. The function layout of Krueng Aceh River. 
Table 1. The main area of Krueng Aceh River.

\begin{tabular}{|c|c|c|c|}
\hline Zone & Area & Main Function & Utilization \\
\hline Coastal Zone & Along the coast area & Buffer Zone & Mangrove forest, breakwater \\
\hline \multirow{4}{*}{ Eco Zone } & Waste management Area & Sewage Treatment Plant & \\
\hline & Samudera Fishery Area & Marine and Fisheries Center & $\begin{array}{l}\text { Fishing port, fishery activity, fish market, fishing } \\
\text { industry }\end{array}$ \\
\hline & Historic Area & $\begin{array}{l}\text { Historical site of Aceh Kingdom and } \\
\text { Islamic Civilization }\end{array}$ & Building and cultural heritage objects \\
\hline & Lampulo & Residence & Low density housing \\
\hline \multirow{2}{*}{$\begin{array}{l}\text { Traditional City } \\
\text { Center Zone }\end{array}$} & Old Town Area & Historical and Cultural Center & $\begin{array}{l}\text { Heritage buildings, } \\
\text { traditional market, culinary tourism, cultural } \\
\text { center, public facilities, commercial activity }\end{array}$ \\
\hline & Baiturrahman Grand Mosque Area & City's Landmark & $\begin{array}{l}\text { Islamic center, religious tourism, Government } \\
\text { center, offices, trade and service area }\end{array}$ \\
\hline Urban & Iskandar Muda Complex & Military Area & Defense and security, sport center, public facilities \\
\hline \multirow{2}{*}{$\begin{array}{l}\text { Development } \\
\text { Zone }\end{array}$} & Lambhuk-Ilie-Pango & Residence & Medium density housing \\
\hline & Lamseupeung-Panteriek-Lueng Bata & Residence & High density housing \\
\hline
\end{tabular}

Source: Analysis data.

Table 2. Strategic plan.

\begin{tabular}{|c|c|c|}
\hline Development Concept & Strategy & Application \\
\hline Islamic-based & City's Identity Reflection & $\begin{array}{l}\text { - Strengthening the identity of Islamic City. } \\
\text { - Reflecting religious ethics in daily life. }\end{array}$ \\
\hline & Aesthetic Image & $\begin{array}{l}\text { - Realizing the city with a high cultural value. } \\
\text { - Promoting the characteristic of Acehnese Culture to attract visitors and tourists. }\end{array}$ \\
\hline Cultural-enriched & $\begin{array}{l}\text { Local Product Economic } \\
\text { Development }\end{array}$ & $\begin{array}{l}\text { - Developing micro economy to increase local community income. } \\
\text { - Supporting craft industry to improve creativity and to enhance business opportunity } \\
\text { independently for local community. } \\
\text { - Increasing economic growth from local to global. }\end{array}$ \\
\hline River-oriented & $\begin{array}{l}\text { Attractive Ecological } \\
\text { Entertainment } \\
\text { Water Transportation System }\end{array}$ & $\begin{array}{l}\text { - Arranging a continuous waterfront and connected with urban activities. } \\
\text { - Providing comfortable public space for community activities. } \\
\text { - Easily accessed for people to enjoy the river view. } \\
\text { - Creating natural experience to maintain and to preserve environment. } \\
\text { - Encouraging community for walking and cycling on the riverside. } \\
\text { - Bringing up recreational facilities to be used by public. } \\
\text { - Supporting the water network as a waterway along the river. } \\
\text { - Making a new tourist destination as water tourism in the future. }\end{array}$ \\
\hline
\end{tabular}

\section{Conclusion}

Based on its role in supporting community activities since the early development of the city and the existence of Baiturrahman Grand Mosque as a landmark of the city, there has great historical value to strengthen the city's identity of Banda Aceh as Islamic City and enriched by the characteristics of Acehnese Culture on 
riverside area. All of regulations and urban policies have been declared in Urban Spatial Plan of Banda Aceh Municipality 2009-2029 that along Krueng Aceh Riverbank is included into protected area and strategic area at once. Integration with waterfront development, the riverbank of Krueng Aceh River is developed to support water transportation system in line with its utilization for Waterfront City (WFC) development and also expected to be a Central Business area in the future. So that, Krueng Aceh River has appropriateness to become an attractive waterfront as public space.

Compiling a comprehensive strategic plan can generate new opportunities as a conceptual urban design in the field that can be discussed for further research. In the implementation, it may take several years to obtain the successful development of urban waterfront. It needs to learn more from the experienced cities to explore the way of new generation on their waterfront redevelopment. By good improvement on riverside area, it can achieve some advantages such as better river environment, be the center of community activity, natural outdoor leisure and beautiful scenic spot of the city.

\section{Acknowledgements}

We wish to thank Government of Banda Aceh that has allowed official data from several institutions in order to obtain accurate information for the research. We also thank all parties that have helped in completing this paper.

\section{Conflicts of Interest}

The authors declare no conflicts of interest regarding the publication of this paper.

\section{References}

Breen, A., \& Rigby, D. (1994). Waterfronts. Cities Reclaim Their Edge. McGraw-Hill Inc., New York.

Chen, Y. (2009). Transformation of Waterfront Space in Asian Cities: Macau, Hong Kong, Shanghai. The 4th International Conference of the International Forum on Urbanism (IFoU), Delft, Netherlands, 597-606.

Davidson, M. (2009). Waterfront Development. In R. Kitchin, \& N. Thrift (Eds.), International Encyclopedia of Human Geography (pp. 215-221). Amsterdam: Elsevier. https://doi.org/10.1016/B978-008044910-4.01111-1

Erkök, F. (2009). Waterfront: Potentials for Improving the Quality of Urban Life. Istanbul Technical University Faculty of Architecture, 6, 126-145.

Global Waterfront Talk (2016). Waterfront Urban Regeneration. Shanghai: Shanghai Jiao Tong University Press.

Government of Banda Aceh City (2008). Development Guidance of Krueng Aceh River Segment II, 2008. (In Indonesian)

Government of Banda Aceh City (2009a). Regional Regulation of Banda Aceh City No.4 Year of 2009. (In Indonesian)

Government of Banda Aceh City (2009b). Urban Spatial Planning of Banda Aceh 2009-2029. 
(In Indonesian)

Ministry of Public Works and People's Housing of Indonesia (2011). Minister Regulation of Public Works and People's Housing No. 20 year of 2011. (In Indonesian)

Pramesti, R. E. (2017). Sustainable Urban Waterfront Redevelopment: Challenge and Key Issues. Media Matrasain, 14, 1858-1137.

Statistics of Banda Aceh City (2018) Banda Aceh City in Figure 2018.

Wu, J., Li, J. W., \& Ma, Y. (2019). Exploring the Relationship between Potential and Actual of Urban Waterfront Spaces in Wuhan Based on Social Network. Sustainability, 11, 3298. https://doi.org/10.3390/su11123298 